\title{
Bionomic of Anopheles sp. in Merauke District, Papua
}

\author{
Djoko Rahardjo $^{1 *}$, Vinsa Cantya Prakasita ${ }^{1}$, and Marlen Aviati Sarah Pepiana ${ }^{1}$ \\ ${ }^{1}$ Faculty of Biotechnology, Duta Wacana Christian University, Yogyakarta, Indonesia
}

\begin{abstract}
Malaria is known as an endemic disease that often causes death in Indonesia, especially in Papua. The malaria cases control in Papua has not been carried on based on data studies, therefore bionomic of Anopheles $\mathrm{sp}$ is important to be studied. Bionomics data are consisted of breeding places, resting places and feeding habits are from direct observation. Interviews and questionnaires were conducted to gain information about respondent behavior. Descriptive and qualitative data were then analyzed. The breeding places of Anopheles sp. were mostly found in swampy areas. Based on the feeding habit, the feeding activity of Anopheles sp. inside the house has only one biting peak at 23.00-02.00 WIT, while outside the house, biting peaks occurred at 21.00-22.00 WIT and 00.00-01.00 WIT. Resting place data shown that Anopheles sp. mostly found in piles of clothes and shoe racks. Recorded factors that affect mosquitos bionomics are temperature, humidity, salinity, $\mathrm{pH}$, community behavior, and the presence of livestock: Environmental factors (temperature, humidity, salinity, and $\mathrm{pH})$, habitual behavior of host (3M action, the habit of using insect repellent, mosquito repellent, and mosquito nets), the presence of livestock, and the type of bait blood type affect mosquito activity.
\end{abstract}

Keywords: Mosquito, Anopheles sp., Bionomics, Merauke

\section{Introduction}

Papua is one of the provinces in Indonesia with high endemic level of malaria. As recorded in 2012, the Annual Parasite Incidence was 77 per 1000 population and Annual Malaria Incidence was 214 per 1000 population. One district in Papua that has high case of malaria is Merauke district. Based on the last 3 years data from the Disease Prevention and Control Division, Health Office of Merauke District, it was found that malaria cases were reported to be fluctuating, but tended to increase.

The main vector of malaria is mosquito belong to genus of Anopheles sp. Environmental conditions, such as climate and heavy rainfall in Merauke, making it an endemic area of malaria (Sukowati, 2008). Control efforts that have been made are not optimal, there are still many outbreaks that occur in this area. This phenomenon could be caused by lack of bionomics data of mosquito that could be useful for malaria

\footnotetext{
* Corresponding author:

Djoko Rahardjo

Faculty of Biotechnology, Duta Wacana Christian University, Jl. Dr. Wahidin Sudirohusodo 5-25, Yogyakarta, Indonesia, 55224

E-mail: djoko@staff.ukdw.ac.id
}

disease control. Bionomic data can be used as initial data in developing effective and well-targeted control strategies. Bionomics is important to study because each type of mosquito has different characteristics, therefore bionomics information of Anopheles sp. in malaria-endemic areas like in Merauke, Papua are very important as a basis to determine effective control strategies to reduce the case of malaria. The objectives of this research is to find out the bionomic mosquito Anopheles sp. including breeding place, feeding place, and resting place.

\section{Materials and Methods}

This research consists of 3 stages. First stage is determining the location of data collection, second stage is the measurement of the parameters and the number of mosquitoes in the area and the third stage is interviews of local community to gain daily behavior data.

\section{Data Collection}

Determination of the location of the study was carried out based on incidents of malaria case data from the Health Office of Merauke District. Based on the data, there were 5 villages with the highest cases of malaria (Karang Indah, Kelapa Lima, Rimba Jaya, and Samkai). One village that has not been 
reported (Mandala) was used as a control. Each breeding place, feeding place, and resting place data are observed and recorded.

\section{Bionomic of Anopheles sp.}

Breeding Place.

Identification of breeding places that are potential places for mosquitoes to breed was directly observed. Areas such as swamps, gutters, puddles, and ponds are further observed to identify the possibility of these area are used for breeding. Mosquito larvae found in any observed water body area were taken and counted using a hand counter.

\section{Feeding Place.}

Identification of feeding place was performed using Human Landing Collecting (HLC) technique with 2 respondents. The respondent sat inside and outside the house wearing shorts and without mosquito repellent. Observation of Anopheles sp. feeding time were conducted at 18.00-06.00 WIT. HLC process consisted of 40 minutes of mosquito feeding activities on respondent and 20 minutes for respondent to rest. During observations, after every one hour HLC process, one hour resting time for respondent was provided. Mosquitoes that land or bite were visually observed. The number of mosquitoes were counted using a hand counter and recorded.

\section{Resting Place.}

The identification of resting place was done by direct observation on the location that allows mosquitoes to rest. On these location, mosquitoes were identified by visual observation and loops, and then to be collected using mosquito spray. The number of mosquitoes inside and outside the house were counted and recorded from 18.00-05.00 WIT.

\section{Factors that Affect Mosquito Bionomics Demographics}

Demographic data such as area width and number of human population were provided by Central Statistics Agency of Merauke District. Respondents data include age, gender, education level, and occupation were obtained from the interview.

\section{Community Behavior}

Interviews were carried out on the behavior of surrounding communities related to Malaria. This aims to find out public knowledge about how they carry out the control of vectors (mosquitoes).

\section{Environmental Parameters}

Some environmental parameters such as temperature, humidity, salinity, and $\mathrm{pH}$ were measured as follows: water and air temperatures were measured with a thermometer, humidity was measured using a hygrometer, salinity of water in aquatic ecosystems was measured with a refractometer, while its $\mathrm{pH}$ value was measured using $\mathrm{pH}$ paper.

\section{Data analysis.}

Data collected from this research were descriptively analyzed.

\section{Results \\ Bionomic of Mosquitos}

Bionomics of mosquito is referred to mosquito behavior and their habitat, including breeding places, feeding habit, and resting places after biting. Permanent ditches (constructed from concrete) are often found as breeding places, followed by puddles, swamps, mud holes, unproductive ponds, natural ditches, and beach water. Based on the type of area, the number of mosquito larvae was highly found in the breeding places of swamps and concrete ditches, followed by mud holes, unproductive ponds, puddles, beach water, and nonconcrete ditch (Table 1).

The peak activity of feeding inside the house occurred at 23.00-00.00 WIT for Karang Indah, Samkai, and Mandala sampling area, while in Rimba Jaya and Kelapa Lima, feeding time peak occurred at 00.00-02.00 WIT. Outside the house, the peak activity of feeding occurred twice: between 21.00-23.00 WIT and 00.00-01.00 WIT. Complete feeding time of Anopheles sp in the research site is shown on table 2 .

Mosquitoes will rest after doing feeding activity. Twenty one places in the research location were identified as resting places for Anopheles sp. both inside and outside the 
Table 1. Breeding place and the number of larvae of Anopheles sp.

\begin{tabular}{|c|c|c|c|c|c|c|c|c|}
\hline \multirow[b]{2}{*}{ Breeding Place (BP) } & \multirow{2}{*}{$\begin{array}{l}\text { The } \\
\text { Number of }\end{array}$} & \multicolumn{7}{|c|}{ Location } \\
\hline & & $\begin{array}{l}\text { Karang } \\
\text { Indah }\end{array}$ & $\begin{array}{c}\text { Rimba } \\
\text { Jaya }\end{array}$ & $\begin{array}{l}\text { Kelapa } \\
\text { Lima }\end{array}$ & Samkai & Mandala & Total & $\begin{array}{c}\text { Percentage } \\
(\%)\end{array}$ \\
\hline \multirow[t]{2}{*}{ Swamp } & $\mathrm{BP}$ & 4 & 4 & 3 & 2 & 0 & 13 & 20.63 \\
\hline & Larvae & 65 & 57 & 16 & 22 & 0 & 160 & 50.47 \\
\hline \multirow{2}{*}{ Concrete Ditch } & BP & 8 & 1 & 6 & 3 & 6 & 24 & 38.10 \\
\hline & Larvae & 20 & 5 & 29 & 9 & 24 & 87 & 27.44 \\
\hline \multirow{2}{*}{ Puddle } & BP & 5 & 1 & 2 & 3 & 3 & 14 & 22.22 \\
\hline & Larvae & 7 & 0 & 0 & 4 & 0 & 11 & 3.47 \\
\hline \multirow{2}{*}{ Unproductive Pond } & BP & 3 & 0 & 0 & 0 & 0 & 3 & 4.76 \\
\hline & Larvae & 13 & 0 & 0 & 0 & 0 & 13 & 4.10 \\
\hline \multirow{2}{*}{ Mud hole } & $\mathrm{BP}$ & 0 & 4 & 0 & 2 & 1 & 7 & 11.11 \\
\hline & Larvae & 0 & 10 & 0 & 9 & 2 & 21 & 6.62 \\
\hline \multirow{2}{*}{ Nonconcrete ditch } & BP & 0 & 0 & 1 & 0 & 0 & 1 & 1.59 \\
\hline & Larvae & 0 & 0 & 3 & 0 & 0 & 3 & 0.95 \\
\hline \multirow{2}{*}{ Beach Water } & BP & 0 & 0 & 0 & 1 & 0 & 1 & 1.59 \\
\hline & Larvae & 0 & 0 & 0 & 5 & 0 & 5 & 1.58 \\
\hline
\end{tabular}

Table 2. Feeding Habit Anopheles sp. Inside and Outside the House

\begin{tabular}{|c|c|c|c|c|c|c|c|}
\hline \multirow{2}{*}{ Time } & \multirow{2}{*}{ Area } & \multicolumn{5}{|c|}{ Location } & \multirow{2}{*}{ Total } \\
\hline & & Karang Indah & Rimba Jaya & Kelapa Lima & Samkai & Mandala & \\
\hline \multirow{2}{*}{$18.00-19.00$} & Inside & 3 & 2 & 2 & 1 & 1 & 9 \\
\hline & Outside & 3 & 2 & 2 & 3 & 4 & 14 \\
\hline \multirow{2}{*}{$19.00-20.00$} & Inside & 5 & 2 & 2 & 3 & 1 & 13 \\
\hline & Outside & 2 & 3 & 4 & 4 & 5 & 17 \\
\hline \multirow{2}{*}{$20.00-21.00$} & Inside & 6 & 1 & 3 & 3 & 2 & 16 \\
\hline & Outside & 2 & 5 & 5 & 5 & 6 & 23 \\
\hline \multirow{2}{*}{$21.00-22.00$} & Inside & 6 & 1 & 4 & 3 & 3 & 19 \\
\hline & Outside & 5 & 5 & 6 & 6 & 7 & 29 \\
\hline \multirow{2}{*}{$22.00-23.00$} & Inside & 7 & 3 & 4 & 4 & 3 & 20 \\
\hline & Outside & 6 & 6 & 5 & 4 & 6 & 27 \\
\hline \multirow{2}{*}{$23.00-00.00$} & Inside & 8 & 5 & 4 & 5 & 4 & 24 \\
\hline & Outside & 6 & 4 & 4 & 3 & 3 & 20 \\
\hline \multirow{2}{*}{ 00.00-01.00 } & Inside & 5 & 6 & 5 & 5 & 3 & 24 \\
\hline & Outside & 7 & 3 & 3 & 5 & 5 & 23 \\
\hline \multirow{2}{*}{ 01.00-02.00 } & Inside & 4 & 5 & 6 & 4 & 3 & 22 \\
\hline & Outside & 8 & 1 & 4 & 4 & 3 & 20 \\
\hline \multirow{2}{*}{$02.00-03.00$} & Inside & 3 & 4 & 4 & 4 & 1 & 18 \\
\hline & Outside & 6 & 2 & 5 & 3 & 3 & 18 \\
\hline \multirow{2}{*}{$03.00-04.00$} & Inside & 3 & 3 & 3 & 2 & 0 & 11 \\
\hline & Outside & 5 & 2 & 0 & 2 & 2 & 11 \\
\hline \multirow{2}{*}{ 04.00-05.00 } & Inside & 1 & 2 & 2 & 1 & 0 & 6 \\
\hline & Outside & 3 & 1 & 0 & 2 & 2 & 8 \\
\hline \multirow{2}{*}{$05.00-06.00$} & Inside & 0 & 1 & 0 & 1 & 0 & 2 \\
\hline & Outside & 2 & 0 & 0 & 1 & 0 & 3 \\
\hline
\end{tabular}

house as shown in Table 3 and 4. Mosquitoes favorable resting place inside the house could be mentioned as follows: piles of clothes, walls, curtains, space under tables, sofa, dipper, and flower vase. On the other hand, the preferred resting place outside the house are shoe rack, area under tree canopy, helmets, trash can, black buckets, coconut shells, flower pots, motorcycle dashboard, and pile of scrap metal. 
Table 3. Resting Place and Number of Mosquitoes Inside the House

\begin{tabular}{|c|c|c|c|c|c|c|c|}
\hline \multirow[b]{2}{*}{ Resting Place (RP) } & \multirow{2}{*}{$\begin{array}{c}\text { The Number } \\
\text { of }\end{array}$} & \multicolumn{5}{|c|}{ Location } & \multirow[b]{2}{*}{ Total } \\
\hline & & $\begin{array}{l}\text { Karang } \\
\text { Indah }\end{array}$ & Rimba Jaya & $\begin{array}{c}\text { Kelapa } \\
\text { Lima }\end{array}$ & Samkai & Mandala & \\
\hline \multirow{2}{*}{ Wall } & $\mathrm{RP}$ & 6 & 7 & 3 & 6 & 4 & 15 \\
\hline & Mosquitoes & 23 & 23 & 13 & 15 & 7 & 81 \\
\hline \multirow{2}{*}{ Piles of Clothes } & RP & 8 & 5 & 6 & 5 & 5 & 19 \\
\hline & Mosquitoes & 30 & 24 & 24 & 13 & 14 & 105 \\
\hline \multirow{2}{*}{ Sofa } & RP & 4 & 2 & 0 & 0 & 3 & 12 \\
\hline & Mosquitoes & 17 & 7 & 0 & 0 & 11 & 35 \\
\hline \multirow{2}{*}{ Space Under Tables } & RP & 3 & 3 & 4 & 4 & 4 & 15 \\
\hline & Mosquitoes & 18 & 10 & 15 & 12 & 9 & 64 \\
\hline \multirow{2}{*}{ Curtains } & RP & 5 & 4 & 6 & 6 & 4 & 15 \\
\hline & Mosquitoes & 21 & 15 & 23 & 14 & 13 & 86 \\
\hline \multirow{2}{*}{ Flower Vase } & RP & 2 & 1 & 3 & 3 & 2 & 8 \\
\hline & Mosquitoes & 3 & 1 & 10 & 6 & 6 & 26 \\
\hline \multirow{2}{*}{ Dipper } & $\mathrm{RP}$ & 0 & 2 & 0 & 4 & 3 & 12 \\
\hline & Mosquitoes & 0 & 6 & 0 & 7 & 6 & 19 \\
\hline
\end{tabular}

\section{Factors that Affect Mosquito Bionomics}

Total area of study site is $88.23 \mathrm{~km}^{2}$ with population of 68,879 people (Badan Pusat Statistik, 2019). As shown in Table 5 , respondents are dominated by men, age intervals of 26-36 years, high school education level, and work as government officer. Respondents were also questioned about their daily health practice of preventing infectious diseases caused by mosquitoes such as use of mosquito nets, use of mosquito coils and repellent and also application of $3 \mathrm{M}$ actions (menguras, menutup dan mengubur) which are translated to draining, closing, and burying).

The measurement of environmental conditions on the research location resulted in the following information: water temperature $\left(27^{\circ} \mathrm{C}-31^{\circ} \mathrm{C}\right)$, air temperature $\left(28-32^{\circ} \mathrm{C}\right)$, humidity (58-80\%), $\mathrm{pH}(6-7)$, and salinity (014 per mill), which could affect the abundance of mosquito larvae in research site.

\section{Discussion}

\section{Breeding place of Anopheles sp.}

Based on observations, concrete ditch (38.10\%) were found as Anopheles sp. favorite breeding place, followed by puddle $(22.22 \%)$, swamp $(20.63 \%)$, mud hole $(11.11 \%)$, unproductive ponds $(4.76 \%)$, non-concrete ditch $(1.59 \%)$ and beach water $(1.59 \%)$ (Table $1)$. Concrete ditches and puddles were found in all research locations, and preferred by mosquitos for lying eggs. This finding is in line with research from Sucipto (2011), which states that mosquito larvae like aquatic ecosystems that are not too deep. Swamp is also another favorite breeding place for mosquitoes in all villages in research location, except in Mandala villages because the village is dominated by shops and highways, therefore no swamp ecosystem was found.

In addition to breeding location data, number of mosquito larvae in those areas were counted. The highest number of larvae was found in Karang Indah, while the lowest one was found in Mandala. There is a difference in the number of mosquito larvae between five locations. The highest number of mosquito larvae was found in the swamps $(50.47 \%)$. This phenomenon could be supported by swamp condition as stagnant water ecosystem with plants around it that can become a shelter for larvae from predators or sunlight. Anopheles sp. larvae also found in concrete ditch $(27.44 \%)$, mud holes $(6.62 \%)$, unproductive ponds $(4.1 \%)$, puddles $(3.47 \%)$, beach water $(1.58 \%)$, and non-concrete ditch $(0.95 \%)$ (Table 1$)$.

The intensity of the rain was quite high at the time of research, therefore many puddles were found. This situation is favored by Anopheles sp. larvae. Shallow puddles allow larvae which have complete organs to grow 
Table 4. Resting Place and Number of Mosquitoes Outside the House

\begin{tabular}{|c|c|c|c|c|c|c|c|}
\hline \multirow[b]{2}{*}{ Resting Place (RP) } & \multirow[b]{2}{*}{ The Number of } & \multicolumn{5}{|c|}{ Location } & \multirow[b]{2}{*}{ Total } \\
\hline & & $\begin{array}{l}\text { Karang } \\
\text { Indah }\end{array}$ & $\begin{array}{c}\text { Rimba } \\
\text { Jaya }\end{array}$ & $\begin{array}{c}\text { Kelapa } \\
\text { Lima }\end{array}$ & Samkai & Mandala & \\
\hline \multirow{2}{*}{ Raincoat Hangers } & $\mathrm{RP}$ & 5 & 1 & 0 & 0 & 4 & 10 \\
\hline & Mosquitoes & 19 & 3 & 0 & 0 & 13 & 35 \\
\hline \multirow{2}{*}{ Trash Can } & $\mathrm{RP}$ & 3 & 0 & 0 & 3 & 3 & 9 \\
\hline & Mosquitoes & 2 & 0 & 0 & 6 & 5 & 13 \\
\hline \multirow{2}{*}{ Helmets } & $\mathrm{RP}$ & 5 & 3 & 3 & 0 & 4 & 15 \\
\hline & Mosquitoes & 17 & 7 & 11 & 0 & 8 & 43 \\
\hline \multirow{2}{*}{ Dashboard motorcycle } & $\mathrm{RP}$ & 3 & 0 & 0 & 0 & 2 & 5 \\
\hline & Mosquitoes & 11 & 0 & 0 & 0 & 6 & 17 \\
\hline \multirow{2}{*}{ Shoe Rack } & RP & 4 & 4 & 5 & 2 & 6 & 21 \\
\hline & Mosquitoes & 14 & 13 & 22 & 2 & 11 & 62 \\
\hline \multirow{2}{*}{ Area under tree canopy } & RP & 3 & 5 & 4 & 5 & 0 & 17 \\
\hline & Mosquitoes & 10 & 18 & 18 & 15 & 0 & 61 \\
\hline \multirow{2}{*}{ Paints Bucket } & RP & 0 & 0 & 2 & 0 & 4 & 6 \\
\hline & Mosquitoes & 0 & 0 & 5 & 0 & 7 & 12 \\
\hline \multirow{2}{*}{ Black Bucket } & $\mathrm{RP}$ & 0 & 4 & 0 & 0 & 5 & 9 \\
\hline & Mosquitoes & 0 & 15 & 0 & 0 & 10 & 25 \\
\hline \multirow{2}{*}{ Flower Pots } & RP & 0 & 4 & 3 & 0 & 0 & 7 \\
\hline & Mosquitoes & 0 & 9 & 6 & 0 & 0 & 15 \\
\hline \multirow{2}{*}{ Pile of Wood } & RP & 0 & 3 & 4 & 0 & 0 & 7 \\
\hline & Mosquitoes & 0 & 10 & 18 & 0 & 0 & 28 \\
\hline \multirow{2}{*}{ Pile of Scrap Metal } & RP & 0 & 0 & 0 & 3 & 0 & 3 \\
\hline & Mosquitoes & 0 & 0 & 0 & 6 & 0 & 6 \\
\hline \multirow{2}{*}{ Coconut Shells } & RP & 0 & 0 & 0 & 8 & 0 & 8 \\
\hline & Mosquitoes & 0 & 0 & 0 & 22 & 0 & 22 \\
\hline \multirow{2}{*}{ Boat } & RP & 0 & 0 & 0 & 6 & 0 & 6 \\
\hline & Mosquitoes & 0 & 0 & 0 & 19 & 0 & 19 \\
\hline
\end{tabular}

(Hoedojo and Sungkar, 2008). In addition to breeding sites depth, the intensity of sunlight affects the number of mosquito larvae. The high intensity of sunlight causes the temperature to rise, so mosquito larvae will not be found. The low intensity of sunlight at the study led to the rarity of the number of mosquito larvae. Sunlight intensity was closely related to weather conditions with high rainfall during the study.

Breeding places in the form of ditches were used as reservoir by mosquito larvae. Based on observations, we found two types of the ditch, which are ditch with flowing water and ditch with stagnant water. In Karang Indah, Kelapa Lima, and Mandala villages, most ditches found is with stagnant water, while in the Rimba Jaya and Samkai villages ditches with flowing water were found. Water flow affects the number of mosquito larvae. More mosquito larvae are found in ditches with stagnant water, because they can avoid the threat from their natural predators such as tilapia fish (Tillapia mossambica). Tilapia is one of the typical fish from Merauke District. This supported the study of Setyaningrum (1998), who mentioned that the more fish populations, the fewer mosquito larvae. In addition, Mattimu (1989), stated that tilapia fish can eat mosquito larvae in flowing water.

\section{Feeding Habit of Anopheles sp.}

Anopheles sp. feeding activity can be took place inside or outside the human dormitory. In this research, feeding activity of mosquitoes was performed using human bait with the HLC method from evening until dawn on 18.00-06.00 WIT.

Feeding activity inside the house was conducted in the living room. Based on the time of biting, observation in Karang Indah, Samkai, and Mandala villages showed early 
Table 5. Demographic characteristics and behavior of respondents in Merauke

\begin{tabular}{|c|c|c|c|c|c|c|c|}
\hline \multirow{2}{*}{ No. } & \multirow{2}{*}{ Parameter } & \multicolumn{6}{|c|}{ Location } \\
\hline & & Rimba Jaya & Karang Indah & Kelapa Lima & Samkai & Mandala & Total \\
\hline 1 & Total Area $\left(\mathrm{km}^{2}\right)$ & 26,7 & 23,04 & 17,03 & 15,72 & 5,74 & 88,23 \\
\hline \multirow[t]{3}{*}{2} & Population & 19.536 & 8.695 & 16.392 & 8.303 & 15.953 & 68.879 \\
\hline & \multicolumn{7}{|c|}{ Ages } \\
\hline & $15-25$ & 1 & 1 & 2 & 3 & 1 & 8 \\
\hline \multirow[t]{4}{*}{3} & $26-36$ & 8 & 5 & 5 & 3 & 5 & 26 \\
\hline & $37-47$ & 1 & 3 & 3 & 4 & 3 & 14 \\
\hline & $48-58$ & 0 & 1 & 0 & 0 & 1 & 2 \\
\hline & \multicolumn{7}{|c|}{ Gender } \\
\hline \multirow[t]{4}{*}{4} & $\mathrm{~L}$ & 4 & 6 & 7 & 5 & 6 & 28 \\
\hline & $\mathrm{P}$ & 6 & 4 & 3 & 5 & 4 & 22 \\
\hline & \multicolumn{7}{|c|}{ Work } \\
\hline & Civil Servants & 1 & 5 & 3 & 1 & 4 & 14 \\
\hline \multirow{7}{*}{5} & Trader & 1 & 2 & 0 & 3 & 5 & 11 \\
\hline & Housewife & 2 & 3 & 4 & 2 & 1 & 12 \\
\hline & Farmers & 0 & 1 & 0 & 3 & 0 & 4 \\
\hline & Fisherman & 2 & 0 & 3 & 1 & 0 & 6 \\
\hline & Stock Farmer & 2 & 0 & 1 & 0 & 0 & 3 \\
\hline & \multicolumn{7}{|c|}{ Education's Level } \\
\hline & Elementary School & 4 & 0 & 1 & 1 & 0 & 6 \\
\hline \multirow[t]{5}{*}{6} & Middle School & 2 & 2 & 2 & 3 & 3 & 12 \\
\hline & High School & 2 & 3 & 6 & 3 & 4 & 18 \\
\hline & College & 2 & 5 & 3 & 3 & 3 & 16 \\
\hline & \multicolumn{7}{|c|}{ Respondent's Behavior } \\
\hline & $\mathrm{MN}$ & 7 & 2 & 8 & 6 & 7 & 30 \\
\hline \multirow[t]{3}{*}{7} & $\mathrm{MC}$ & 10 & 8 & 10 & 4 & 10 & 42 \\
\hline & $\mathrm{R}$ & 0 & 0 & 6 & 1 & 9 & 16 \\
\hline & $3 \mathrm{M}$ & 3 & 0 & 8 & 5 & 9 & 25 \\
\hline
\end{tabular}

MN: Using Mosquito Nets, MC: Habit of Using Mosquito Coils, R: Using Repellent, 3M: menguras, menutup dan mengubur or closing, draining, burying.

Table 6. Environmental parameters and number of mosquito larvae found in sampling site

\begin{tabular}{|c|c|c|c|c|c|c|}
\hline \multirow[t]{2}{*}{ Breeding Place } & \multicolumn{5}{|c|}{ Environmental Condition } & \multirow{2}{*}{$\begin{array}{l}\text { Number } \\
\text { of Larva }\end{array}$} \\
\hline & $\begin{array}{l}\text { Water Temperature } \\
\left({ }^{\circ} \mathrm{C}\right)\end{array}$ & $\begin{array}{c}\text { Air Temperature } \\
\left({ }^{\circ} \mathrm{C}\right)\end{array}$ & $\begin{array}{l}\text { Humidity } \\
(\%)\end{array}$ & $\begin{array}{l}\text { Salinity } \\
\text { (per mill) }\end{array}$ & $\mathrm{pH}$ & \\
\hline Swamp & $28-29$ & $28-32$ & $60-80$ & 0 & $6-7$ & 138 \\
\hline Concrete ditch & $27-31$ & $28-32$ & $58-77$ & 0 & $6-7$ & 57 \\
\hline Puddle & $27-31$ & $28-32$ & $58-60$ & 0 & $6-7$ & 4 \\
\hline Unproductive Pond & $27-29$ & $28-32$ & $60-65$ & 0 & $6-7$ & 13 \\
\hline Mud hole & $29-31$ & $30-32$ & $60-61$ & 0 & $5-6$ & 17 \\
\hline Nonconcrete ditch & $28-29$ & $29-30$ & $60-61$ & 0 & $6-7$ & 5 \\
\hline Beach water & $29-30$ & $30-31$ & $60-61$ & $0-14$ & $7-8$ & 5 \\
\hline
\end{tabular}


biting period, which occurred at 23.00-00.00 WIT, Meanwhile, observation in Rimba Jaya and Kelapa Lima villages showed that peak of Anopheles feeding activity occurred at 00.00-02.00 WIT (Table 2). Similarity between feeding activity period in Karang Indah, Samkai and Mandala villages could be related to the absence of livestock, thus affecting the behavior of mosquitoes in searching for another source of blood. Based on the research by Shinta and Marjana (2015), Anopheles sp also like animal blood (zoophilic). The Ministry of Health of the Republic of Indonesia (2007), through the Directorate General of Disease Control and Environmental Health also mentioned that Anopheles is a zoo-anthropophilic mosquito, which means that the mosquito likes the blood of animals and humans.

The feeding activity outside the house is higher than one inside the house, which has two different time peak. In the first time interval (18.00-19.00), feeding activity in almost all locations were still relatively small, except in Mandala village which showed high feeding activity. In the next time interval, there was an increase of feeding activity in Kelapa Lima, Samkai and Mandala villages until the fourth time interval (21.0022.00 WIT). Observation in Karang Indah and Rimba Jaya villages showed the first peak was only reached at fifth interval (22.00-23.00 WIT). The second increase of mosquito's feeding activity started at 00.00-01.00 WIT in Samkai and Mandala villages, meanwhile this phenomenon was observed in Karang Indah at eighth interval and happened at ninth interval in Rimba Jaya and Kelapa Lima villages.

Factors affecting Anopheles sp. feeding activity were environmental characteristics and activities or behavior of the respondents as well. Humidity was considered to be major environmental factor that affected feeding activity of mosquitoes. Each location where the peak of feeding activities were observed has relatively high humidity, thus supporting the feeding activity. The shortest feeding activity is observed in Mandala village, because of the characterization of that area was dominated by office and shops. Based on direct human behavior observations, people in Mandala village already applied practical ways to tackle the spread of mosquitos such as using mosquito coils, mosquito nets, and repellent so that they can reduce the activity of mosquitoes in the location.

In addition to environmental factors and respondent activities, it is important to consider the criteria for mosquitoes in choosing human target to be bitten. People with $\mathrm{O}$ blood group were preference target for mosquitoes (Prasadini et al., 2019).

\section{Resting place of Anopheles sp.}

After biting, the mosquito will have certain period for resting. Based on observations, 21 places were discovered as Anopheles sp. resting places, both inside and outside human dormitory (Table 3 and 4). Inside the house, clothing pile took the first rank as resting place with a percentage of $20 \%$. Other places that mosquitoes like to rest are wall, curtains, and space under tables that have same percentage $(16 \%)$, then followed by sofa and dipper with the same percentage (12\%). Another resting place like flower vases only contributed $8 \%$ as Anopheles sp. resting place. The preferred types of places as resting places outside the house are shoe racks $(17 \%)$, trees $(14 \%)$, helmets $(12 \%)$, trash bins $(7 \%)$, black buckets $(7 \%)$, coconut shells $(7 \%)$, flower pots $(6 \%)$, motorcycle dashboards $(6 \%)$, and the least desirable is scrap metal (2\%).

In this research, pile of clothes is the most common place that was found as a resting place for Anopheles sp. inside people houses. This finding is in line with Soedarmo et al. (2010), whom stated that one of Anopheles sp. favorite resting places is a pile of clothes. Besides pile of clothes, mosquitoes were found resting on wall, space under tables, curtains, and flower vases. This can be attributed to dark and rarely cleaned places, thus inviting mosquitoes to rest. Mosquitoes are very attracted by the dark color as mentioned by Sardjito (2008). This condition also creates relatively high humidity, thus supported mosquitoes to rest well. Dipper can be used for mosquitoes as a resting place because the majority are found in an open condition with high humidity 
and still located in a wash tub. Sofas were observed as a resting place in all research sites, except in Kelapa Lima and Samkai villages, because majority of respondents use plastic chairs.

Based on the number of resting mosquitoes outside houses, it was observed that the highest number of mosquitoes was found on a shoe rack, while the lowest one was found on a pile of scrap metal. Shoe racks often have a closed design, thus created a humid and dark conditions which Anopheles sp. favored. Mosquitoes were often found under shady and moist trees because that location were well protected from sunlight. Mosquitoes also rest inside helmets because condition of helmets was moist and dark. Because the research was conducted in the rainy season and people often use rain coat for cover, rain coat hangers can be used by mosquito for resting place. This preference was related to the condition of raincoat which were wet and humid. Mosquitoes rest on buckets, both used paint buckets and black buckets. Number of mosquitoes found in the black bucket was more than used paint bucket. This phenomenon could be related to the color factor. Mosquitoes are more attracted to dark colors because dark colors absorb heat more than bright colors. This heat is easily detected by mosquito receptors (palpus). Palpus serves to detect temperature and humidity so that it can distinguish the heat emitted by an object. Therefore, the number of mosquitoes is denser in the black bucket. Coconut shells were found on the seashore. The shell is usually discarded carelessly, causing a puddle of water in it. This condition can be potential place for mosquitoes to rest. In addition to coconut shells, mosquitoes are also found in boats, but not too many. That is because in the boat there are dark areas and left over water. The pile of scrap metal was a resting place that was less favored by mosquitoes. This place has open conditions so that the intensity of sunlight is high and does not allow mosquitoes to rest.

Factors affecting Bionomic of Anopheles sp.

Prevention of malaria disease should be done by people who lives in Malaria endemic area by minimizing the activity of its vector, Anopheles sp. Common ways to tackle the spread of mosquitos such as using mosquito coils, mosquito nets, and repellent should be conducted in daily life. Observation from research site informed that most people in all villages in this study uses mosquito repellent as prevention. Most respondent from Mandala village was noted to use mosquito repellent, while people in Rimba Jaya and Karang Indah village do not use repellent. Using of mosquito nets is not popular in the community of Karang Indah village. People in Mandala and Kelapa Lima were known to be familiar and take action on $3 \mathrm{M}$ program as suggested by the government, while Karang Indah residents had not yet taken the action.

Bionomics of Anopheles sp. consists of breeding, feeding, and resting places are affected by many factors. Not only from the mosquitoes environmental factors are also very closely related to the bionomic of Anopheles sp. Based on observations, it was found environmental conditions such as water temperature $27^{\circ} \mathrm{C}-31^{\circ} \mathrm{C}$, air temperature $28^{\circ} \mathrm{C}-32^{\circ} \mathrm{C}$, humidity $58-80 \%$, pH 6-7, salinity 0-14 per mill with the total number of mosquito larvae under these conditions is 0-65 larvae (Table 6).

This study showed that temperature condition in research site was still in range to support mosquito larvae to live. Optimum temperature for Anopheles sp. is $20^{\circ} \mathrm{C}-30^{\circ} \mathrm{C}$. Water temperature affects the hatching of mosquito eggs. Increased water temperature will support mosquito eggs to hatch faster (Susanna, 2010). Humidity is closely related to temperature. Temperature and humidity have a positive correlation with the number of mosquito larvae. In conditions of environmental humidity below $60 \%$, no mosquito larvae were found, meanwhile if humidity conditions is more than $60 \%$, mosquito larvae were found. This is in line with research by Suwito et al. (2010). The minimum humidity level for mosquitoes to live is $60 \%$. Higher humidity conditions allow more active mosquitoes to bite. Most of the salinity at the research location is zero per mile, except in the Samkai with a value of 5 per mile and the highest is 14 per mile 
in coastal water. Anopheles species such as Anopheles farautii and Anopheles hilli has a high tolerance level for salinity conditions (Kawulur et al., 2015, Shinta and Marjana., 2015, \& Sandy, 2014). Those two Anopheles species are able to live at high salinity beach ecosystem, but not all member of Anopheles sp. According to Sukowati (2014), Anopheles sp. has a tolerance for salinity up to $25 \%$, so that it can still be found in beach waters. Besides salinity, water $\mathrm{pH}$ also affects the number of mosquito larvae. Based on observations, it is discovered that mosquito larvae are found in water body with $\mathrm{pH}$ value of 6 . These results are in line with the study from Septiani (2012), whom mentioned $\mathrm{pH}$ value range at which mosquito larvae can survive is 5-8, with an optimum pH 7.91-8.09.

\section{Conclusion}

Bionomic of Anopheles sp. based on breeding places are found in swamp habitats, gutters, and places with dark and moist puddles. The peak feeding activity inside the house occurs at 23.00-00.00 WIT, while outside the house occurs at 21.00-23.00 WIT and 00.00-01.00 WIT. Pile of clothes and shoe racks are the most popular places for mosquitoes to rest. Environmental factors (temperature, humidity, salinity, and $\mathrm{pH}$ ), habitual behavior of host (3M action, the habit of using insect repellent, mosquito repellent, and mosquito nets), the presence of livestock, and the type of bait blood type affect mosquito activity.

\section{Acknowledgment}

The authors would like to thank the Faculty of Biotechnology, Duta Wacana Christian University for the research funding support and the Health Department of Merauke District, Papua, for granting permission and supporting research.

\section{References}

Badan Pusat Statistik. (2019). Jumlah Penduduk Dan Rasio Jenis Kelamin Kabupaten Merauke 2010-2017. https:// meraukekab.bps.go.id/ dynamictable/2018/04/26/8/jumlah- penduduk-dan-rasio-jenis-kelaminkabupaten-merauke-2010-2017.html

Hoedojo, R \& Sungkar, S. (2008). Morfologi, Daur Hidup, dan Perilaku Nyamuk: Parasitologi Kedokteran. Edisi ke 4. Jakarta: Fakultas Kedokteran, Universitas Indonesia.

Kawulur, H., Soesilohadi, H.R.C., Hadisusanto, S., \& Trisyono, A. (2015). Perilaku Vektor Malaria Anopheles farauti Laveran (Diptera: Culicidae) di Ekosistem Pantai (Kabupaten Biak Numfor) dan Ekosistem Rawa (Kabupaten Asmat) Provinsi Papua. Bioma, 17(1), pp. 34-40.

Prasadini, M., Dayananda, D., Fernando, S., Harischandra, I., \& De Silva, N. (2019). Blood Feeding Preference of Female Aedes aegypti Mosquitoes for Human Blood Group Types and Its Impact on Their Fecundity: Implications for Vector Control. American Journal of Entomology 3(2): 43-48.

Mattimu, A. (1989). Studi Laboratorium Potensi Ikan Mujair (Oreochromis mossambicus Peters) Untuk Pengendalian Hayati Larva Anopheles aconitus D. Tesis Pasca Sarjana. Bogor: IPB.

Sandy, S. (2014). Bionomi Vektor Malaria Kelompok Anopheles punctulatus (Anopheles farautii, Anopheles koliensis, Anophelespunctulatus) di Provinsi Papua. BALABA, 10(1), pp. 47-52.

Windarso, S., Rubaya, A.K., Suwerda, B., \& Ganefati S.P. (2008). Studi Bionomik Vektor Malaria di Kecamatan Kalibawang Kulonprogo. JRL 4(2), pp. 111-117.

Septiani, L. (2012). Studi Ekologi Tempat Perindukan Vektor Malaria Di Desa Sukamaju Kecamatan Punduh Pedada Kabupaten Pesawaran Propinsi Lampung. Skripsi. Lampung: Unila.

Setyaningrum, E., Murwani, S., Rosa, E., \& Andananta, K. (2008). Studi Ekologi Perindukan Nyamuk Vektor Malaria di Desa Way Muli, Kecamatan Lampung Selatan. Prosiding Seminar Hasil Penelitian dan Pengabdian kepada Masyarakat, pp. 292-299. 
Shinta \& Marjana, P. (2015). Distribusi dan Perilaku Vektor Malaria di Kabupaten Merauke. Buletin Penelitian Kesehatan, 43(4), pp. 219-230.

Soedarmo, S. S. P., Garna, H., Hadinegoro, S.R.S., \& Satari, H. I. (2010). Buku Ajar Infeksi dan Pediatri Tropis. Jakarta: IDIAI.

Sucipto, C. D. (2011). Vektor Penyakit Tropis. Yogyakarta: Gosyen Publishing.

Sukowati, S \& Shinta. (2014). Habitat Perkembangbiakan dan Aktivitas Mengigit Nyamuk Anopheles sundaicus dan Anopheles subpictus di Purworejo, Jawa Tengah. Jurnal Ekologi Kesehatan, 8(1), pp 915-925.

Sukowati, S. (2008). Masalah Keragaman Spesies Vektor Malaria dan Cara Pengendaliannya di Indonesia. Orasi Pengukuhan Profesor Riset Bidang Biologi Lingkungan. Jakarta: Badan Penelitian dan Pengembangan Kesehatan, Departemen Kesehatan.

Susanna, D \& Eryando, T. (2011). Faktor Dominan yang Mempengaruhi Kejadian Malaria di Perdesaan. Jurnal Kesehatan Masyarakat Nasional, 4(4), pp. 180-185.

Suwito., Hadi, U. K., Sigit, S. H., \& Sukowati S. (2010). Hubungan Iklim, Kepadatan Nyamuk Anopheles dan Kejadian Penyakit Malaria. Jurnal Entomologi Indonesia, 7(1), pp. 42-53. 